\title{
A model of nitrogen efficiency in contrasting grass-based dairy systems
}

\author{
W. Ryan, ${ }^{\star} \dagger$ D. Hennessy, ${ }^{\star 1}$ J. J. Murphy, ${ }^{*}$ T. M. Boland,† and L. Shalloo* \\ *Animal and Grassland Research and Innovation Centre, Teagasc, Moorepark, Fermoy, Co. Cork, Ireland \\ †School of Agriculture, Food Science and Veterinary Medicine, University College Dublin, Belfield, Dublin 4, Ireland
}

\begin{abstract}
Nitrogen $(\mathrm{N})$ efficiency is one of the key drivers of environmentally and economically sustainable agricultural production systems. An $\mathrm{N}$ balance model was developed, evaluated, and validated to assess $\mathrm{N}$ use efficiency and $\mathrm{N}$ surplus and to predict $\mathrm{N}$ losses from contrasting grass-based dairy production systems in Ireland. Data from a 5-yr study were used to evaluate and validate the model. Grass-based and high-concentrate production systems combined with 3 divergent strains of Holstein-Friesian (HF) dairy cows - high-production North American (HP), high-durability North American (HD), and New Zealand (NZ) - were evaluated. As concentrate input increased, $\mathrm{N}$ surplus per hectare increased and $\mathrm{N}$ use efficiency per hectare decreased (23 and $10 \%$, respectively). When the $\mathrm{N}$ required to rear replacement animals to maintain the production system was considered, the $\mathrm{N}$ surplus of the $\mathrm{HP}$ genetic strain was greater $(156 \mathrm{~kg}$ of $\mathrm{N} / \mathrm{cow})$ than that of the HD (140 $\mathrm{kg}$ of $\mathrm{N} / \mathrm{cow})$ or the NZ (128 kg of N/cow). The model estimated $\mathrm{N}$ leaching of $8.1 \mathrm{mg}$ of $\mathrm{NO}_{3}-\mathrm{N} / \mathrm{L}$, similar to that measured by others at the same site. The model creates awareness of methods and indicators available to assess the most suitable and environmentally sustainable grass based dairy production systems.
\end{abstract}

Key words: nitrogen balance, grassland, dairy, nitrogen use efficiency

\section{INTRODUCTION}

Grassland-based agricultural production is the most important component of livestock production systems in Ireland and in other temperate regions (Dillon et al., 2005) because of the competitive economic advantage of grazed grass within such a system. In recent years, increased world demand for food and a continual reduction in market prices has resulted in increased focus on grass-based systems of production. In Ireland and other temperate regions, intensive grass-based milk production systems generally rely on inputs of nitrogen $(\mathrm{N})$

Received March 26, 2010.

Accepted October 24, 2010.

${ }^{1}$ Corresponding author: deirdre.hennessy@teagasc.ie in the form of chemical fertilizer to produce sufficient herbage (grazed grass or grass silage), and strategic concentrate supplementation during times of herbage deficit, to sustain milk output per hectare at economically viable levels. In 2007, the average Irish dairy farm had a stocking rate of 1.9 livestock units $(\mathbf{L U}) /$ ha, fed approximately $700 \mathrm{~kg}$ of concentrates per cow, and applied $175 \mathrm{~kg}$ of $\mathrm{N} / \mathrm{ha}$, although concentrate feeding and $\mathrm{N}$ application varied with stocking rate (Teagasc, 2007).

Despite the positive effect of $\mathrm{N}$ fertilizer use on agricultural production (Whitehead, 1995), the poor efficiency with which $\mathrm{N}$ is utilized within animal-based systems is well documented (Watson and Atkinson, 1999). As $\mathrm{N}$ cycles through the farm system unavoidable losses occur by 3 major loss pathways: nitrate $\left(\mathrm{NO}_{3}{ }^{-}\right)$ leaching, nitrous oxide $\left(\mathrm{N}_{2} \mathrm{O}\right)$ emissions, and ammonia $\left(\mathrm{NH}_{3}\right)$ volatilization (Whitehead, 1995).

Achieving the optimum balance between profitable agriculture and environmental protection is challenging. When production is maximized and output is near equilibrium, all further $\mathrm{N}$ inputs are lost to the environment (Rotz et al., 2005). Generally, as feed N intake increases, $\mathrm{N}$ output in feces, urine, and milk increases (Castillo et al., 2000); $\mathrm{NH}_{3}$ emissions increase (Misselbrook et al., 2006); $\mathrm{N}_{2} \mathrm{O}$ emissions increase (Hyde et al., 2005); and $\mathrm{NO}_{3}{ }^{-}$leaching increases (Ledgard et al., 1999; Richards, 1999). However, negative relationships were found between $\mathrm{N}$ input and the level of $\mathrm{N}$ utilization; often increasing $\mathrm{N}$ inputs decreases $\mathrm{N}$ use efficiency. Humphreys et al. (2003) noted that reducing $\mathrm{N}$ input by $246 \mathrm{~kg}$ of $\mathrm{N} / \mathrm{ha}$ on an intensive dairy production system while maintaining similar levels of production improved $\mathrm{N}$ use efficiency by $29 \%$. However, an increase of $\mathrm{N}$ use efficiency may come at the expense of animal and plant production (Laws et al., 2000), highlighting that a balance has to be achieved between $\mathrm{N}$ use efficiency and $\mathrm{N}$ losses to maintain a sustainable dairy production system.

European Union (EU) policy such as the Water Framework Directive $(2000 / 60 / E C)$ and the Nitrates Directive (SI 378 2006), as well as recent sharp increases in the cost of $\mathrm{N}$ fertilizer, have increased the focus on $\mathrm{N}$ use efficiency. The Nitrates Directive sets limits 
Table 1. Herd performance data generated by the Moorepark Dairy Systems Model for 9 contrasting pasture-based dairy production systems ${ }^{1}$

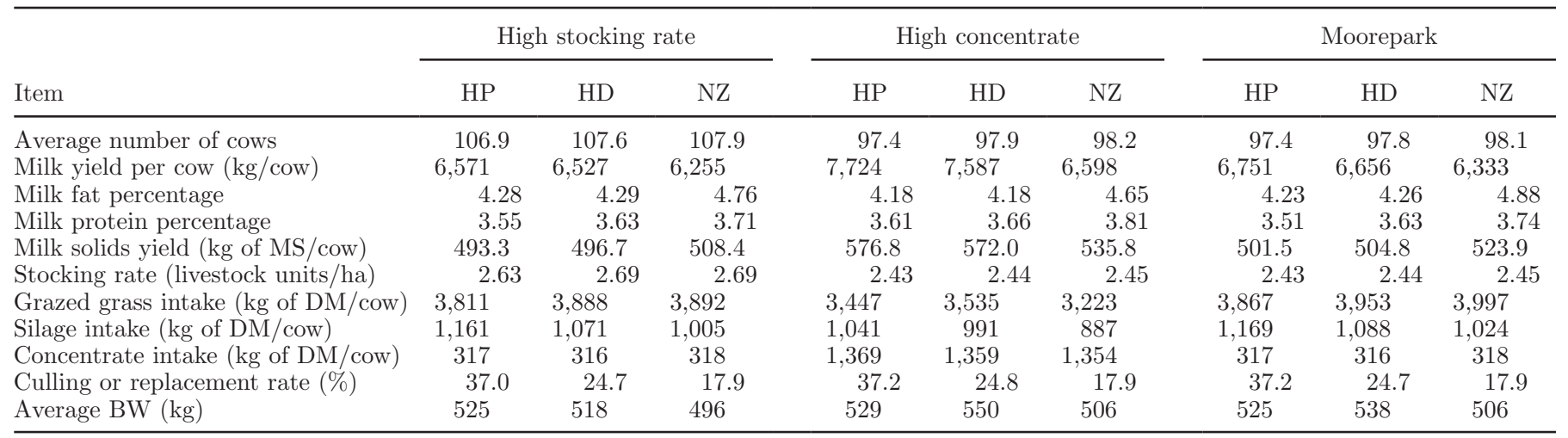

${ }^{1}$ Divergent strains of Holstein-Friesian cows consisting of high-production North American (HP), high-durability North American (HD), and New Zealand (NZ).

on stocking rate and $\mathrm{N}$ fertilizer use per hectare. In Ireland, water quality surveys, including $\mathrm{NO}_{3}{ }^{-}$levels, over the last 2 decades show a steady decrease in water quality, which has largely been attributed to agricultural activity (EPA, 2006).

Estimates of the potential quantities of $\mathrm{N}$ that may be released into the environment from dairy farms have been calculated using $\mathrm{N}$ budgets and models within numerous production systems (Scholefield et al., 1991; Mounsey et al., 1998; Watson and Atkinson, 1999; del Prado et al., 2006; Humphreys et al., 2008) with surpluses ranging from 2.1 to more than $300 \mathrm{~kg}$ of $\mathrm{N} /$ ha (Mounsey et al., 1998; Watson et al., 2002). Few of these budgets attempt to quantify and model the $\mathrm{N}$ flows and losses associated with the different levels of production and the related environmental and economic consequences.

Computer simulation provides a tool for rapid and cost-effective synopsis of the performance of agriculture systems (Rotz et al., 2005). However, a limitation of this approach is developing confidence in the simulation results. Only through extensive verification and evaluation of the model will confidence be gained in the results and recommendations. Comparison of model results with actual recorded information is the only meaningful way to validate farm models (Shalloo et al., 2004).

The objectives of this study were to develop, evaluate, and validate an annual $\mathrm{N}$ balance model based on Irish grass-based dairy production systems. The balance is in monthly stages from January to December. The production and economic performance of the systems was generated by the Moorepark Dairy Systems Model (MDSM; Shalloo et al., 2004). The model developed and described in this paper evaluates $\mathrm{N}$ balances and quantifies $\mathrm{N}$ use efficiency by identifying surpluses and potential losses associated with contrasting levels of production within grass-based, spring-calving dairy production systems.

\section{MATERIALS AND METHODS}

\section{Dairy Production System Physical Performance}

The dairy production systems that were simulated during model validation and scenario testing are on grass-based dairy systems with a February to April calving pattern. The physical performance data were obtained from a 5-yr study (2001-2006) conducted at Curtins Research Farm, Animal and Grassland Research and Innovation Centre, Teagasc, Moorepark, Fermoy, Co. Cork, Ireland.Farm system production data were generated by the MDSM based on the physical performance at Curtins Farm. The study consisted of 3 divergent strains of Holstein-Friesian (HF) dairy cows: high-production North American (HP), highdurability North American (HD), and New Zealand (NZ), managed across a variety of Irish pasture-based production systems: the Moorepark Blueprint system (MP), a high concentrate input system $(\mathbf{H C})$, and a high stocking rate system (HS). This study is described in detail by Horan et al. (2004) and McCarthy et al. (2007) (Table 1).

The physical performance of each dairy production system used for the scenarios assessed is described in Table 1. As the genetic strain of dairy cow and level of concentrate supplementation changed, the milk production, milk solids concentration, feed budgets, and overall farm stocking rate changed, as has previously been reported by McCarthy et al. (2007) (Table 1).

The land base for each treatment was similar (40 ha), and the grazing season length and housing periods were similar for all 9 treatments. The information includes the number of dairy cows per treatment, annual feed 
budget (grazed grass, conserved silage, and purchased concentrate), and production performance (annual milk production). The meteorological data used were the 4-yr mean monthly rainfall recorded by Ryan et al. (2006). The quantity of annual effective rainfall (precipitation minus evapotranspiration; $459 \mathrm{~mm}$ ) was used in the model to calculate the quantity of $\mathrm{NO}_{3}{ }^{-}$leached (Ryan et al., 2006). It is assumed in the validation of the model reported in this paper that all slurry produced within each farm system was recycled on that system.

\section{Moorepark Dairy Systems Model}

The MDSM (Shalloo et al., 2004) is a stochastic budgetary simulation model of a dairy farm. It allows investigation of the effects of varying biological, technical, and physical processes on farm profitability. The model integrates animal inventory and valuation, milk production, feed requirements, land and labor utilization, and an economic analysis of the production system. Land area is treated as an opportunity cost, with additional land rented when required and leased out when not required for on-farm feeding of animals. Variable costs (fertilizer, contractor charges, medical and veterinarian fees, artificial insemination, silage, and reseeding), fixed costs (machinery maintenance and running costs, farm maintenance, car, telephone, electricity, and insurance), and prices (calf, milk, and cow) are based on 2008 management data for farm planning (Teagasc, 2008). The quantity of each feed offered (grass, grass silage, and concentrate) was determined by the MDSM to meet the net energy requirements of animals for maintenance, milk production, and BW change (Jarrige, 1989).

\section{Model Description}

The flow or cycle of $\mathrm{N}$ within a system is the movement of $\mathrm{N}$ between several reservoirs. Within any grass-based production system, $\mathrm{N}$ enters the system in the form of imported inorganic and organic fertilizers, concentrate feed, and symbiotic and nonsymbiotic $\mathrm{N}$ capture (Jarvis et al., 1995; Figure 1). This N resides temporarily in various reservoirs, including the plants and their residues and grazing or housed livestock, and may be exchanged from one form to another (e.g., from $\mathrm{NH}_{4}{ }^{+}$to $\mathrm{NO}_{3}{ }^{-}$). Livestock cause chemical and biological transformations to the cycling $\mathrm{N}$ through digestion, excretion, and exportation (Jarvis et al., 1995). Nitrogen within the herbage is relocated through the grazing process, where $\mathrm{N}$ in herbage grazed from a large area will be redistributed to small, highly concentrated areas through the deposition of urine and dung (Haynes and Williams, 1993). Ingested $\mathrm{N}$ is also transformed into $\mathrm{N}$ exports such as milk and meat sold, recycled N, or N lost to the environment (Whitehead, 1995).

\section{Nitrogen Balance Calculations}

The sum of the annual inputs less outputs in the form of agricultural products is the farm-gate $\mathrm{N}$ balance (Scholefield et al., 1991; Watson and Atkinson, 1999). The farm-gate $\mathrm{N}$ balance takes account of all $\mathrm{N}$ imported into the dairy system, circulated within, and exported from the dairy system (Figure 1). Imports and exports of $\mathrm{N}$ can be expressed on a per hectare $(\mathrm{kg} / \mathrm{ha})$ or a per cow $(\mathrm{kg} / \mathrm{cow})$ basis. Nitrogen use efficiency was calculated as the proportion of imported $\mathrm{N}$ recovered in agricultural products.

Nitrogen Inputs. The $\mathrm{N}$ imported into the farm system consisted of fertilizer, feedstuffs, and livestock (in the form of replacement or purchased animals). No legumes were present in the swards. Nitrogen input into the individual cow consisted of $\mathrm{N}$ in feed consumed (grazed grass, silage, and concentrates) and $\mathrm{N}$ required to replace the individual cow. Cows were replaced as culling occurred within the herd due to fertility, health, and production-related factors. The replacement rate for each system is shown in Table 1. Body weight of replacement animals was assumed to be $80 \%$ that of a mature cow to simulate a younger cow replacing an older cow with a similar $\mathrm{N}$ content. Other $\mathrm{N}$ inputs taken account of are atmospheric deposition and soil N mineralization (Scholefield et al., 1991; Watson and Atkinson, 1999).

Nitrogen imported in the form of chemical fertilizer was expressed as kilograms of $\mathrm{N}$ applied per hectare. Nitrogen imported in concentrate feed was calculated by multiplying the total quantity of concentrate fed by its CP content and dividing by 6.25 (McDonald et al., 1995). The $\mathrm{N}$ content of the grazed grass and grass silage harvested was calculated by dividing the CP by 6.25 (Mc Donald et al., 1995). The quantity of atmospheric $\mathrm{N}$ deposited each year was taken as $9 \mathrm{~kg} / \mathrm{ha}$ per year, as estimated by Ryan et al. (2006).

Nitrogen Outputs. The N outputs from the farm system can be divided in 2 categories: (1) N leaving the system in products (milk, meat, exported feedstuff and exported manure); and (2) $\mathrm{N}$ immobilized in the soil or lost through volatilization, denitrification, or leaching.

Nitrogen in milk exported from the farm was calculated from recorded milk protein content of milk (milk protein divided by 6.39 ; ARC, 1994) multiplied by milk volume. Nitrogen exported in livestock leaving the farm was calculated by estimating the total live weight of the livestock sold (or died) from the system (Horan et al., 2004; McCarthy et al., 2007) and multiplying it by 


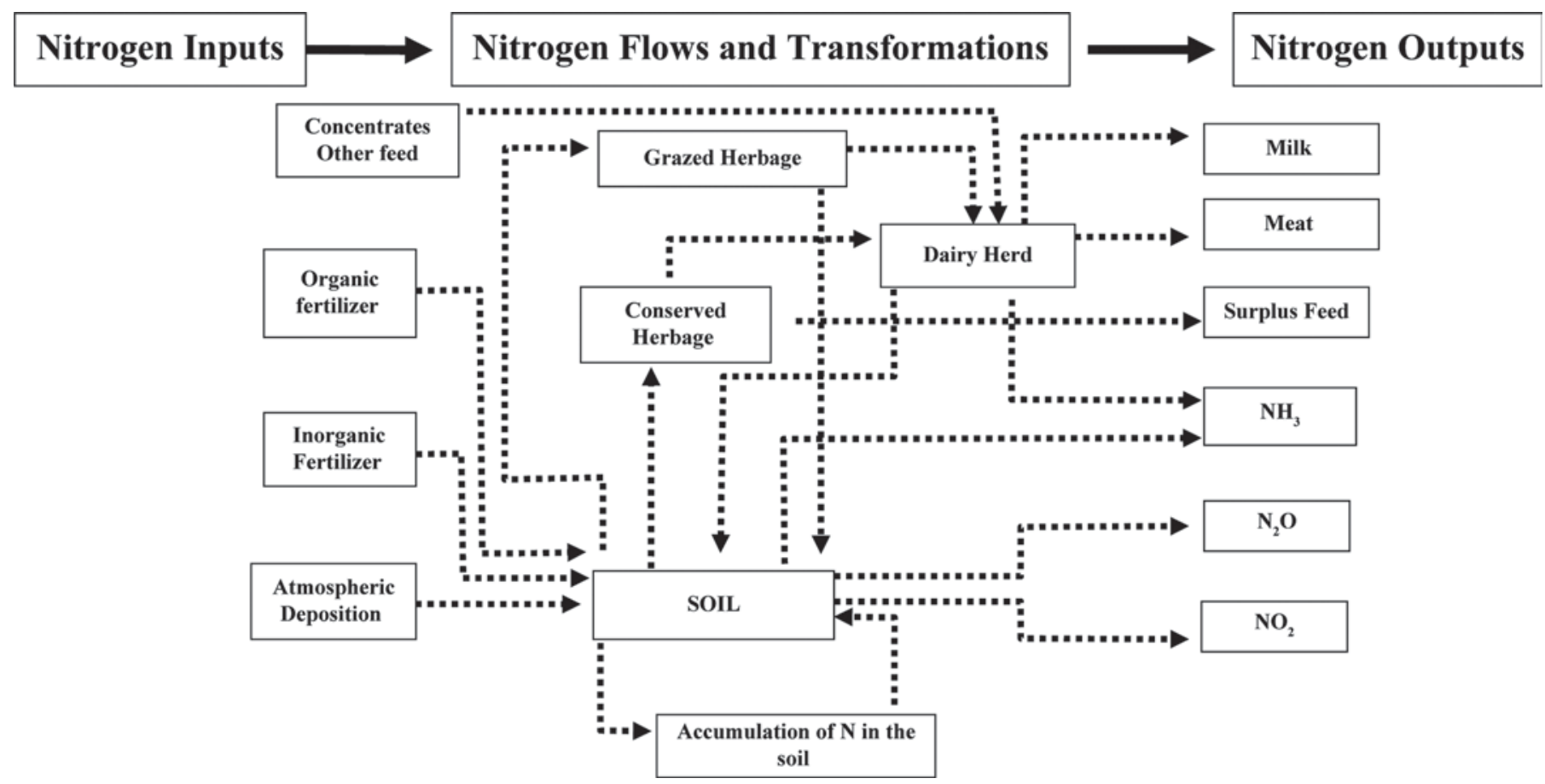

Figure 1. Flow diagram of $\mathrm{N}$ inputs, $\mathrm{N}$ outputs, and flows, and the major pathways for $\mathrm{N}$ losses within a grass-based dairy system.

the $\mathrm{N}$ content. The $\mathrm{N}$ content of exported calves born on the farm and dairy cows sold from the farm was estimated as 0.029 and $0.024 \mathrm{~kg}$ of $\mathrm{N} / \mathrm{kg}$ of live weight, respectively (ARC, 1994).

Nitrogen Cycling Within the System. Nitrogen produced as slurry during the housed period was calculated as total $\mathrm{N}$ intake (in the form of grazed grass, silage, and concentrate) consumed by the housed animals less $\mathrm{N}$ output from these animals and $\mathrm{N}$ used for growth and maintenance (Watson and Atkinson, 1999). The slurry was reapplied to the land area within the farm system.

Soil Nitrogen. Soil N mineralization (average annual $\mathrm{N}$ flux) was estimated using the 5 -yr mean of $\mathrm{N}$ harvested in herbage $(\mathrm{kg}$ of $\mathrm{N} / \mathrm{ha})$ from grass growth plots receiving no fertilizer $\mathrm{N}$ (methodology described by Corrall and Fenlon, 1978) at the Animal and Grassland Research and Innovation Centre, Teagasc, Moorepark, and the methods described by del Prado et al. (2006) as shown in equation [1]:

$\mathrm{SNM}(\mathrm{kg}$ of $\mathrm{N} / \mathrm{ha})=\{[($ Harvested, $\mathrm{kg}$ of $\mathrm{N} / \mathrm{ha}, \times 1.4)$

$$
\times \text { Pcf }] \times \operatorname{Dstf}\}-\mathrm{Ad},
$$

where $\mathrm{SNM}=$ soil $\mathrm{N}$ mineralization, $\mathrm{Pcf}=$ previous cropping history combined with sward age adjustment factor (long-term pasture $>2$ yr Pcf $=1$ ), Dstf $=$ drainage and soil texture adjustment factor (good drainage on sandy loam soil type Dstf $=0.75)$, and Ad = atmosphere deposition ( $\mathrm{kg}$ of $\mathrm{N} / \mathrm{ha}$ ).

The annual accumulation and addition of soil organic $\mathrm{N}$ was estimated as the sum of $\mathrm{N}$ from ungrazed herbage and fecal $\mathrm{N}$ deposited to the soil during the grazing season (Hutchings and Kristeensen, 1995), plus $\mathrm{N}$ transferred to roots, based on an annual root production of $5,000 \mathrm{~kg} / \mathrm{ha}$ (Whitehead, 1995), with a root $\mathrm{N}$ content of $1.2 \%$ (Whitehead, 1970).

Animal Excreta. The N content of cow excreta was estimated by subtracting $\mathrm{N}$ in milk, maintenance, and live weight gain from total $\mathrm{N}$ intake (del Prado et al., 2006). The N portion of dung in excreta was calculated by the methods described by del Prado et al. (2006) and shown in equation [2]:

$\mathrm{N}$ in dairy cow dung $=0.15 \times \mathrm{N}_{\text {animal intake }}+28.47$. [2]

Nitrogen content of urine was calculated from total N in the excreta minus the $\mathrm{N}$ in dung (del Prado et al., 2006).

\section{Nitrogen Losses}

Nitrogen Losses from Volatilization. Losses of $\mathrm{NH}_{3}$ through volatilization from grazed grassland were estimated using the methods described by Misselbrook et al. (2006) and shown in equation [3]: 
$\mathrm{NH}_{3}-\mathrm{N}$ emission $(\mathrm{g} / \mathrm{LU}$ per day $)=-0.51+0.0742 \mathrm{X}$,

where $\mathrm{X}=$ input of fertilizer $\mathrm{N}$ ( $\mathrm{kg}$ of $\mathrm{N} /$ ha per $\mathrm{yr}$ ).

Losses of $\mathrm{NH}_{3}-\mathrm{N}$ during agitation and application of slurry were assumed to be 0.60 of $\mathrm{NH}_{3}-\mathrm{N}$ in the slurry (Pain et al., 1989, 1990). A housing emission factor of $34.5 \mathrm{~g}$ of $\mathrm{NH}_{3}-\mathrm{N} / \mathrm{LU}$ per day was also included (Hyde et al., 2003).

Nitrogen Losses from Denitrification and Leaching and Unaccountable $N$. Denitrification and leaching losses were assumed to be the difference between $\mathrm{N}$ inputs to the soil (fertilizer, atmosphere mineralization, urine, dung, and dead plant material) and $\mathrm{N}$ uptake by the plant component of the sward, $\mathrm{NH}_{3}$ volatilization from urine and dung (Scholefield et al., 1991), and $\mathrm{N}$ accumulation within the soil (Watson and Atkinson, 1999). The proportion of $\mathrm{N}$ attributed to denitrification loss was derived according to soil type and a drainage category factor of 0.15 , as described by Scholefield et al. (1991). This factor is related to the texture and type of soil; for example, a free-draining sandy loam soil type is classified with a factor of 0.15 , whereas a poorly drained heavy clay soil is classified with a factor of 0.80; thus, less denitrification takes place on free-draining soils compared with poorly drained soils. The proportion of the remaining loss was attributable to leachable $\mathrm{N}$ and so was obtained by difference (Scholefield et al., 1991; del Prado et al., 2006).

The potential $\mathrm{N}$ concentration in groundwater was estimated using the crop and soil type specific leaching fraction of 0.24. This was based upon the specific crop, previous management, and soil type, using methods described by Boumans et al. (2001), Fraters et al. (2005), and Schroder et al. (2009), and shown in equation [4]:

$$
\mathrm{NO}_{3} \text { in groundwater }(\mathrm{mg} / \mathrm{L})=\frac{\mathrm{N}_{\text {sal }} \times \mathrm{C}_{\text {slf }}}{\text { Effective rainfall }(\mathrm{mm})} \text {, }
$$

where $\mathrm{N}_{\text {sal }}=$ surplus $\mathrm{N}$ available for leaching ( $\mathrm{kg}$ of $\mathrm{N} /$ ha), $\mathrm{C}_{\text {slf }}=$ crop and soil type specific leaching fraction of 0.24 , and effective rainfall $(\mathrm{mm})=$ precipitation evapotranspiration.

Unaccountable $\mathrm{N}$ was the difference between $\mathrm{N}$ inputs and $\mathrm{N}$ outputs and measured or calculated $\mathrm{N}$ losses.

\section{Scenario Investigation, Sensitivity Analysis, and Model Validation}

Two scenarios were investigated in the evaluation and validation of the model. Scenario 1 (S1) investigated the $\mathrm{N}$ utilization, $\mathrm{N}$ use efficiency, and $\mathrm{N}$ losses of the contrasting dairy production systems described by Horan et al. (2004) and McCarthy et al. (2007), excluding the $\mathrm{N}$ required to rear replacement animals from birth to first calving necessary for the production system. An $\mathrm{N}$ value for the animal used to replace culled cows is included. This scenario is the typical farm-gate $\mathrm{N}$ balance and is calculated on a per hectare basis to allow comparison with previously published work, and on a per cow basis to compare $\mathrm{N}$ use efficiency between contrasting dairy cow strains.

Scenario 2 (S2) investigated the $\mathrm{N}$ utilization, $\mathrm{N}$ use efficiency, and $\mathrm{N}$ losses on each of the 9 dairy production systems described by Horan et al. (2004) and McCarthy et al. (2007), including the $\mathrm{N}$ required to rear replacement animals from birth to first calving. The $\mathrm{N}$ balance for this scenario was calculated on a per cow basis to quantify the level of efficiency at which the cow utilizes $\mathrm{N}$ for production purposes.

A sensitivity analysis was undertaken in which the effect of reducing fertilizer $\mathrm{N}$ application by $50 \mathrm{~kg}$ of $\mathrm{N} /$ ha while maintaining the same levels of production through improved grass utilization was examined. Comparisons of farm-gate $\mathrm{N}$ balance on a per hectare basis, $\mathrm{N}$ utilization, $\mathrm{N}$ use efficiency, and $\mathrm{N}$ losses per hectare were made.

The model was validated using data from Ryan et al. (2006) in which $\mathrm{NO}_{3}{ }^{-}-\mathrm{N}$ leaching to a depth of $1 \mathrm{~m}$ from management areas determined to be representative of the major variables on a dairy grassland farm were measured over a 4-yr period (2001-2005) at the same site (Ryan et al., 2006). The data were used to obtain the $\mathrm{NO}_{3}{ }^{-}$leaching results for comparison with the model results, and therefore model validation.

\section{RESULTS}

\section{Nitrogen Input}

The main sources of $\mathrm{N}$ input to the dairy production systems were feed, fertilizer, and replacement animals. The average quantity of fertilizer applied was $289 \mathrm{~kg}$ of $\mathrm{N} /$ ha $(\mathrm{SD}=1.1 \mathrm{~kg}$ of $\mathrm{N} / \mathrm{ha})$ for all treatments investigated in $\mathrm{S} 1$ (noninclusion of the heifer rearing component; Table 2). The quantity of $\mathrm{N}$ imported per cow in the form of concentrate varied between treatments, ranging from 7 to $31 \mathrm{~kg}$ of N/cow (Table 3 ).

Nitrogen input for S2 (inclusion of the heifer rearing component) increased from $166 \mathrm{~kg}$ of $\mathrm{N} /$ cow to $206 \mathrm{~kg}$ of $\mathrm{N} /$ cow (Table 4) as the replacement rate increased from $18 \%$ for the NZ strain to $37 \%$ for the HP strain, with a mean $\mathrm{N}$ input increase of $66 \mathrm{~kg}$ of $\mathrm{N} /$ ha across the different production systems (Table 4). The quantity of $\mathrm{N}$ utilized in the form of grazed pasture, silage, and concentrate in S2 for heifer rearing varied between 
Table 2. The annual farm-gate $\mathrm{N}$ balance ( $\mathrm{kg}$ of $\mathrm{N} / \mathrm{ha}$ ) and $\mathrm{N}$ use efficiency for scenario 1 , in which $\mathrm{N}$ required for the rearing of replacement was not included in the $\mathrm{N}$ budget of 9 dairy production systems ${ }^{1}$

\begin{tabular}{|c|c|c|c|c|c|c|c|c|c|}
\hline \multirow[b]{2}{*}{ Item } & \multicolumn{3}{|c|}{ High stocking rate } & \multicolumn{3}{|c|}{ High concentrate } & \multicolumn{3}{|c|}{ Moorepark } \\
\hline & HP & HD & $\mathrm{NZ}$ & $\mathrm{HP}$ & $\mathrm{HD}$ & $\mathrm{NZ}$ & $\mathrm{HP}$ & HD & $\mathrm{NZ}$ \\
\hline Fertilizer N & 295.9 & 296.7 & 297.3 & 298.2 & 98.6 & 299.5 & 296.9 & 297.5 & 298.2 \\
\hline $\mathrm{N}$ input in the replacement cows & 10.1 & 6.3 & 4.4 & 8.3 & 5.8 & 4.0 & 9.1 & 6.2 & 4.1 \\
\hline Total $\mathrm{N}$ input & 324.9 & 322.0 & 320.9 & 381.0 & 378.8 & 377.9 & 323.2 & 321.0 & 319.7 \\
\hline Milk N & 94.4 & 96.6 & 94.8 & 102.9 & 103.0 & 93.5 & 87.6 & 89.6 & 88.0 \\
\hline Total N output & 111.4 & 108.8 & 104.5 & 117.2 & 114.3 & 102.4 & 102.8 & 101.3 & 97.1 \\
\hline Nitrogen surplus & 213.5 & 213.2 & 216.3 & 263.8 & 264.5 & 275.5 & 220.4 & 219.8 & 222.6 \\
\hline Nitrogen use efficiency & 0.343 & 0.338 & 0.326 & 0.308 & 0.302 & 0.271 & 0.318 & 0.315 & 0.304 \\
\hline
\end{tabular}

${ }^{1}$ Divergent strains of Holstein-Friesian cows consisting of high-production North American (HP), high-durability North American (HD), and New Zealand (NZ).

genetic strain, with means of 57,83 , and $123 \mathrm{~kg}$ of $\mathrm{N} /$ ha for the NZ, HD, and HP genetic strains, respectively (Table 4).

The total $\mathrm{N}$ intake per cow consumed by dairy replacement animals in S2 (0-2 yr old) varied between genetic strains, depending on replacement rate. It was 23,33 , and $49 \mathrm{~kg}$ of $\mathrm{N} /$ cow consumed for the NZ, HD, and HP genetic strains, respectively (Table 4).

Nitrogen supplied from soil mineralization was estimated, using equation [1], to be $82 \mathrm{~kg}$ of $\mathrm{N} / \mathrm{ha}$ for all treatments, based on the 5-yr average grass growth rates from plots receiving zero $\mathrm{N}$ fertilizer.

\section{Nitrogen Outputs}

Milk production was the main source of exported $\mathrm{N}$ from all dairy production systems, with $\mathrm{N}$ exported in milk ranging from 88 to $103 \mathrm{~kg}$ of $\mathrm{N} /$ ha (Table 2). The increase in replacement rate had a positive effect on the quantity of $\mathrm{N}$ exported in the form of meat in $\mathrm{S} 1$ and $\mathrm{S} 2$, ranging from 6 to $14 \mathrm{~kg}$ of $\mathrm{N} /$ ha (Table 2) or 2 to $5 \mathrm{~kg}$ of $\mathrm{N} /$ cow (Table 3). The overall quantity of $\mathrm{N}$ exported per hectare in the form of product varied from 97 to $117 \mathrm{~kg} /$ ha (Table 2 ).

The quantity of slurry produced and reapplied within each system ranged from 73 to $80 \mathrm{~kg}$ of $\mathrm{N} / \mathrm{ha}$, depending on the number of dairy cows within the system (range from 97 to 108 cows). The number of days housed was the same across treatments $(85 \mathrm{~d})$. Nitrogen immobilization or accumulation within the soil was consistent between treatments at approximately $79 \mathrm{~kg}$ of $\mathrm{N} / \mathrm{ha}$ $(\mathrm{SD}=0.2 \mathrm{~kg}$ of $\mathrm{N} / \mathrm{ha}$; Table 5$)$.

\section{Nitrogen Use Efficiency (Farm Gate)}

The annual farm-gate $\mathrm{N}$ surplus per hectare ( $\mathrm{N}$ inputs less $\mathrm{N}$ outputs in products) ranged from $213 \mathrm{~kg}$ of $\mathrm{N} /$ ha for HP-HS to $275 \mathrm{~kg}$ of N/ha NZ-HC, with a mean $\mathrm{N}$ surplus of $234 \mathrm{~kg}$ of $\mathrm{N} /$ ha for all systems (Table 2). A negative relationship was found between $\mathrm{N}$ surplus

Table 3. The annual $\mathrm{N}$ balance per cow ( $\mathrm{kg}$ of $\mathrm{N} / \mathrm{cow}$ ) and $\mathrm{N}$ use efficiency for scenario 1, in which $\mathrm{N}$ required for the rearing of replacement was not included in the budget for 9 dairy production systems ${ }^{1}$

\begin{tabular}{|c|c|c|c|c|c|c|c|c|c|}
\hline \multirow[b]{2}{*}{ Item } & \multicolumn{3}{|c|}{ High stocking rate } & \multicolumn{3}{|c|}{ High concentrate } & \multicolumn{3}{|c|}{ Moorepark } \\
\hline & $\mathrm{HP}$ & HD & $\mathrm{NZ}$ & $\mathrm{HP}$ & HD & $\mathrm{NZ}$ & $\mathrm{HP}$ & HD & $\mathrm{NZ}$ \\
\hline Silage kg N intake & 26.0 & 24.0 & 22.5 & 23.3 & 22.2 & 19.9 & 26.2 & 24.4 & 22.9 \\
\hline Concentrate $\mathrm{N}$ intake & 7.1 & 7.1 & 7.1 & 30.7 & 30.4 & 30.3 & 7.1 & 7.1 & 7.1 \\
\hline Dairy cow replacement N & 3.8 & 2.3 & 1.6 & 3.4 & 2.4 & 1.6 & 3.7 & 2.5 & 1.7 \\
\hline Total N intake & 146.4 & 145.5 & 143.6 & 156.7 & 157.2 & 145.0 & 148.2 & 148.0 & 147.1 \\
\hline Cull cow $\mathrm{N}$ output & 5.2 & 3.4 & 2.5 & 4.7 & 3.5 & 2.5 & 5.1 & 3.6 & 2.5 \\
\hline Total N output & 41.7 & 40.5 & 38.8 & 48.2 & 46.8 & 41.8 & 42.3 & 41.5 & 39.6 \\
\hline $\mathrm{N}$ surplus & 104.71 & 105.0 & 104.83 & 108.46 & 110.38 & 103.19 & 105.95 & 106.49 & 107.50 \\
\hline $\mathrm{N}$ use efficiency & 0.285 & 0.278 & 0.270 & 0.308 & 0.298 & 0.288 & 0.285 & 0.280 & 0.269 \\
\hline
\end{tabular}

${ }^{1}$ Divergent strains of Holstein-Friesian cows consisting of high-production North American (HP), high-durability North American (HD), and New Zealand (NZ). 
Table 4. The annual $\mathrm{N}$ balance per cow ( $\mathrm{kg}$ of $\mathrm{N} / \mathrm{cow}$ ) and $\mathrm{N}$ use efficiency for scenario 2 , in which all $\mathrm{N}$ required for the rearing of replacement was included in the $\mathrm{N}$ budget of 9 dairy production systems ${ }^{1}$

\begin{tabular}{|c|c|c|c|c|c|c|c|c|c|}
\hline \multirow[b]{2}{*}{ Item } & \multicolumn{3}{|c|}{ High stocking rate } & \multicolumn{3}{|c|}{ High concentrate } & \multicolumn{3}{|c|}{ Moorepark } \\
\hline & $\mathrm{HP}$ & HD & $\mathrm{NZ}$ & $\mathrm{HP}$ & HD & $\mathrm{NZ}$ & HP & $\mathrm{HD}$ & $\mathrm{NZ}$ \\
\hline Concentrate $\mathrm{N}$ intake & 7.1 & 7.0 & 7.1 & 30.7 & 30.4 & 30.3 & 7.1 & 7.1 & 7.1 \\
\hline Dairy cow replacement N & 3.8 & 2.3 & 1.6 & 3.4 & 2.4 & 1.6 & 3.7 & 2.5 & 1.6 \\
\hline Heifer intake grazed pasture & 33.7 & 22.5 & 15.5 & 34.0 & 22.6 & 15.6 & 34.0 & 22.5 & 15.5 \\
\hline Total kg N input & 195.4 & 178.2 & 166.2 & 205.9 & 190.0 & 167.6 & 197.5 & 180.7 & 169.7 \\
\hline Milk N output & 35.4 & 36.0 & 35.1 & 42.3 & 42.1 & 38.1 & 36.0 & 36.7 & 37.0 \\
\hline Calf kg N & 1.2 & 1.2 & 1.2 & 1.2 & 1.2 & 1.2 & 1.2 & 1.2 & 1.2 \\
\hline Cull cow $\mathrm{N}$ output & 5.2 & 3.3 & 2.5 & 4.7 & 3.4 & 2.5 & 5.1 & 3.6 & 2.5 \\
\hline Total N output & 41.7 & 40.5 & 38.8 & 48.2 & 46.7 & 41.8 & 42.2 & 41.5 & 39.6 \\
\hline N surplus & 153.7 & 137.7 & 127.4 & 157.8 & 143.2 & 125.8 & 155.2 & 139.2 & 130.0 \\
\hline $\mathrm{N}$ use efficiency & 0.214 & 0.227 & 0.234 & 0.234 & 0.246 & 0.249 & 0.214 & 0.230 & 0.234 \\
\hline
\end{tabular}

${ }^{1}$ Divergent strains of Holstein-Friesian cows consisting of high-production North American (HP), high-durability North American (HD), and New Zealand (NZ).

and the proportion of grazed herbage in the diet, with the HC feeding systems producing the greatest N surplus while consuming the least amount of grazed grass (Table 2).

When comparing the milk solids (MS) produced ( $\mathrm{kg}$ of MS/ha) and N surplus per hectare, little difference was observed between genetic strains in S1, with a mean of $6 \mathrm{~kg}$ of MS/ha (SD 0.1) produced for every 1 $\mathrm{kg}$ of surplus N. Differences were found between feeding systems in S1, with 5.1, 5.6, and $6.2 \mathrm{~kg}$ of MS/ha produced per $\mathrm{kg}$ of $\mathrm{N}$ surplus per ha for the $\mathrm{HC}, \mathrm{MP}$, and the HS feeding systems, respectively. In S2, strains HD and NZ produced $50 \mathrm{~kg}$ of milk/ $\mathrm{kg}$ of surplus N, which was $10 \%$ more than that of the HP genetic strain.

In the $\mathrm{S} 1$ farm-gate $\mathrm{N}$ balance, the mean level of $\mathrm{N}$ use efficiency was 0.31 , ranging from 0.27 to 0.34 (Table 2). As the level of concentrate supplementation increased, a negative effect on $\mathrm{N}$ use efficiency was found, ranging from a combined mean $\mathrm{N}$ use efficiency of 0.32 for the HS and MP feeding systems to 0.29 for the HC feeding system (Table 2). The quantity of surplus $\mathrm{N}$ available for loss increased as the level of $\mathrm{N}$ efficiency decreased (Table 2). The $\mathrm{N}$ balance on a per cow basis for S1 shows that the HP genetic strain utilized $\mathrm{N}$ most efficiently, at a mean $\mathrm{N}$ use efficiency per cow of 0.29 (Table 3 ).

In S2, when the full dairy production system (including $\mathrm{N}$ required for the heifer rearing component) $\mathrm{N}$ balance was calculated, the $\mathrm{N}$ surplus for the different genetic strains was 323,353 , and $390 \mathrm{~kg}$ of $\mathrm{N} /$ ha for the $\mathrm{NZ}, \mathrm{HD}$, and HP genetic strains, respectively.

Milk solids production per cow per $\mathrm{kg}$ of surplus $\mathrm{N}$ in S2 ranged from 3.2 for the HP strain to 3.9 for the HD and NZ strains. Feeding system had little effect on MS produced per cow per $\mathrm{kg}$ surplus $\mathrm{N}$, with a mean of 3.7 $\mathrm{kg}$ of MS/cow (SD 0.20) produced per $\mathrm{kg}$ of surplus $\mathrm{N}$.

Table 5. The nitrogen $(\mathrm{N})$ surplus ( $\mathrm{kg}$ of $\mathrm{N} /$ ha unless otherwise noted) and estimated annual losses ( $\mathrm{kg}$ of $\mathrm{N} /$ ha) for 9 dairy production systems from scenario $1^{1}$

\begin{tabular}{|c|c|c|c|c|c|c|c|c|c|}
\hline \multirow[b]{2}{*}{ Item } & \multicolumn{3}{|c|}{ High stocking rate } & \multicolumn{3}{|c|}{ High concentrate } & \multicolumn{3}{|c|}{ Moorepark } \\
\hline & HP & HD & $\mathrm{NZ}$ & $\mathrm{HP}$ & HD & NZ & HP & HD & NZ \\
\hline $\mathrm{N}$ in urine excreta & 188.6 & 190.3 & 190.3 & 181.2 & 186.8 & 168.9 & 175.5 & 177.5 & 180.4 \\
\hline Ammonia emissions & 51.4 & 52.1 & 52.4 & 43.6 & 44.1 & 44.4 & 43.4 & 43.8 & 44.2 \\
\hline $\mathrm{N}$ accumulation in the soil & 79.2 & 79.2 & 79.2 & 79.1 & 79.2 & 78.9 & 78.9 & 78.9 & 78.9 \\
\hline $\mathrm{N}$ lost through denitrification & 25.9 & 25.3 & 25.1 & 29.7 & 29.3 & 29.7 & 27.3 & 26.7 & 26.6 \\
\hline Unaccountable $\mathrm{N}^{2}$ & -6.1 & -2.7 & 1.3 & 26.4 & 29.3 & 37.5 & -0.4 & 2.3 & 6.0 \\
\hline
\end{tabular}

${ }^{1}$ Divergent strains of Holstein-Friesian cows consisting of high-production North American (HP), high-durability North American (HD), and New Zealand (NZ).

${ }^{2}$ The difference between $\mathrm{N}$ inputs and $\mathrm{N}$ outputs and measured or calculated $\mathrm{N}$ losses. 
In $\mathrm{S} 2$, the $\mathrm{N}$ balance per cow shows that the HP genetic strain was the least efficient production system, with mean $\mathrm{N}$ use efficiency of 0.23 per cow, whereas the NZ genetic strain was the most efficient production system, with mean $\mathrm{N}$ use efficiency of 0.24 per cow (Table 4). In S2, the NZ genetic strain had the lowest overall mean $\mathrm{N}$ surplus (128 kg of N/cow; Table 4) and produced $4.1 \mathrm{~kg}$ of $\mathrm{MS} / \mathrm{kg}$ of surplus N. Overall, the NZ genetic strain produced approximately 33\% more MS (kg/cow) per $\mathrm{kg}$ of surplus $\mathrm{N}$ than the HP and HD genetic strains.

\section{Nitrogen Losses}

Nitrogen losses to the environment were estimated from S1, as this scenario is typical of farming practice in Ireland, with replacement heifers reared as a separate enterprise to milk production on the farm (usually on an outside block of land away from the milking cow grazing area). Mean $\mathrm{NH}_{3}$ emissions were $47 \mathrm{~kg}$ of $\mathrm{N} /$ ha (Table 5). Ammonia emissions increased from 43 to $52 \mathrm{~kg}$ of $\mathrm{N} / \mathrm{ha}$ as stocking rate and $\mathrm{N}$ input increased (Table 5).

Nitrogen losses from denitrification did not vary hugely between treatments. The mean $\mathrm{N}$ loss from denitrification was $27 \mathrm{~kg}$ of N/ha, ranging from 25 to $30 \mathrm{~kg}$ of N/ha (Table 5). A negative trend was observed between $\mathrm{N}$ efficiency and $\mathrm{N}$ loss through denitrification (Table 5).

The mean N available for leaching was $155 \mathrm{~kg}$ of N/ ha across the dairy production systems, ranging from 142 to $169 \mathrm{~kg}$ of $\mathrm{N} /$ ha (Table 5). The quantity of $\mathrm{N}$ available for leaching tended to change with feeding system. As stocking rate and quantity of grazed grass in the diet increased, the quantity of $\mathrm{N}$ available for leaching decreased. The quantity of concentrates in the diet had a positive effect on the amount of $\mathrm{N}$ available for leaching (Table 5). The mean $\mathrm{N}$ available for leaching was 157,154 , and $154 \mathrm{~kg}$ of N/ha (Table 5) for the $\mathrm{HP}, \mathrm{HD}$, and NZ genetic strains, respectively.

When the $\mathrm{N}$ available for leaching is used to estimate the potential loss of $\mathrm{NO}_{3}{ }^{-}$to groundwater, the mean $\mathrm{N}$ concentrations in groundwater was $8.09 \mathrm{mg}$ of $\mathrm{N} / \mathrm{L}$, ranging from 7.4 to $8.8 \mathrm{mg}$ of $\mathrm{N} / \mathrm{L}$. As feeding system changed from low concentrate input (MP and HS) to high concentrate input ( $\mathrm{HC}$ ), the estimated $\mathrm{N}$ concentration of groundwater increased from 7.8 to $8.8 \mathrm{mg}$ of $\mathrm{N} / \mathrm{L}$, respectively (Table 5).

As the quantity of surplus $\mathrm{N}$ increased, so too did the quantity of $\mathrm{N}$ that was unaccounted for (Table $5)$. When all the $\mathrm{N}$ outputs and losses associated with the different production systems were calculated, the unaccounted-for $\mathrm{N}$ ranged from $-6.1 \mathrm{~kg}$ of $\mathrm{N} /$ ha for HP-HS to $37.6 \mathrm{~kg}$ of N/ha for NZ-HC.

\section{Sensitivity Analysis}

Reducing $\mathrm{N}$ fertilizer input by $50 \mathrm{~kg}$ of $\mathrm{N} /$ ha while maintaining production reduced the $\mathrm{N}$ surplus by a mean of $22 \%$ (SD 0.02 ) relative to $\mathrm{S} 1$, with individual treatment reductions ranging from 18 to $23 \%$. The N use efficiency increased on all treatments by an average of $17 \%$ (SD 0.01) with reduced $\mathrm{N}$ fertilizer application, and $\mathrm{NH}_{3}$ emissions were reduced by an average of $14 \%$. The $\mathrm{N}$ available for leaching was reduced by a mean of $19 \%$ (29 kg of N/ha; SD $0.5 \mathrm{~kg}$ of N/ha), denitrification losses were reduced by $5 \mathrm{~kg}$ of N/ha (SD $0.1 \mathrm{~kg}$ of N/ ha) across all treatments, and groundwater $\mathrm{N}$ concentrations were reduced by a mean of $1.5 \mathrm{mg}$ of $\mathrm{N} / \mathrm{L}$ (SD $0.26 \mathrm{mg}$ of $\mathrm{N} / \mathrm{L})$.

\section{Validation of Production Systems}

The $\mathrm{N}$ surplus per hectare and $\mathrm{N}$ use efficiency estimated for treatments used by Ryan et al. (2006) were $233 \mathrm{~kg}$ of N/ha and 0.32 , respectively. Similar N surpluses and $\mathrm{N}$ efficiencies were calculated by the model reported in this paper. The $\mathrm{N}$ surpluses per cow in $\mathrm{S} 1$ and S2 were 107 and $140 \mathrm{~kg}$ of N/cow, respectively, and $\mathrm{N}$ use efficiency per cow in S1 and S2 was 0.29 and 0.23, respectively.

Nitrogen losses from $\mathrm{NH}_{3}$ emissions and from denitrification reported by Ryan et al. (2006) were 47 and 27 $\mathrm{kg}$ of $\mathrm{N} / \mathrm{ha}$, respectively, which were slightly lower than those estimated by the model. The model estimated similar quantities of $\mathrm{N}$ available for leaching as that reported by Ryan et al. (2006; $154 \mathrm{~kg}$ of N/ha). The N concentration in groundwater calculated by the model was $8.1 \mathrm{mg}$ of $\mathrm{NO}_{3} / \mathrm{L}$, which is similar to the concentration measured by Ryan et al. (2006) of $8.2 \mathrm{mg}$ of $\mathrm{NO}_{3} / \mathrm{L}$ (Table 6).

\section{DISCUSSION}

\section{Production System N Utilization}

The methods used in this study combine field experiments and simulations to understand the dynamics of $\mathrm{N}$ balance in dairy production systems. Modeling the production system showed a mean surplus $\mathrm{N}$ of $234 \mathrm{~kg}$ of N/ha, with $\mathrm{N}$ utilization efficiency ranging from 27 to $34 \%$.

Other studies have reported poor $\mathrm{N}$ use efficiency in Ireland in high $\mathrm{N}$ input systems. Mounsey et al. (1998) and Treacy et al. (2008) reported N surpluses greater than $300 \mathrm{~kg} / \mathrm{ha}$ per year as a result of excessive $\mathrm{N}$ input and moderate $\mathrm{N}$ output per hectare. This is because of the inability of systems to utilize additional $\mathrm{N}$ inputs above those required for herbage and animal production (Whitehead, 1995). The treatments examined in 
this paper had similarly high $\mathrm{N}$ inputs. In S2 (inclusive of heifer rearing component), as the level of $\mathrm{N}$ input increased between the different feeding systems (HS, MP and $\mathrm{HC}$ ), so did $\mathrm{N}$ output in the form of production. However, $40 \%$ of the extra $\mathrm{N}$ input was lost to the environment, highlighting the law of diminishing returns as $\mathrm{N}$ input increases (Rotz et al., 2006). Regardless of production system, at the animal level, over $70 \%$ of $\mathrm{N}$ consumed was excreted in dung or urine. The mean efficiency at which $\mathrm{N}$ was utilized was similar to levels of N efficiency observed by Castillo et al. (2000), who noted that $72 \%$ of $\mathrm{N}$ intake was excreted. The distribution of excreted $\mathrm{N}$ between dung and urine reflects the concentration of $\mathrm{N}$ in the diet (Van Vuuren and Meijs, 1987; Delaby et al., 2007). Excretion of $\mathrm{N}$ in the dung is not affected by changes in the $\mathrm{N}$ concentration of the diet and tends to remain constant at approximately 8 $\mathrm{g}$ of $\mathrm{N}$ per $\mathrm{kg}$ of DM consumed (Whitehead, 1995). A change in the $\mathrm{N}$ concentration of the diet is therefore reflected in the amount of $\mathrm{N}$ excreted in the urine (Van der Meer, 1983; Van Vuuren and Meijs, 1987; Jarvis et al., 1989; Peyraud et al., 1997; Peyraud and Astigarraga, 1998). In the production systems examined, changes in the $\mathrm{N}$ concentration of milk are small relative to the large increases in $\mathrm{N}$ excreted in urine that occurred with increasing $\mathrm{N}$ concentration of the diet. Verite and Delaby (2000) showed that, at grazing, an increase in $\mathrm{CP}$ content of the diet from 18 to $22 \%$ resulted in a $30 \%$ increase in daily excreted $\mathrm{N}$, of which $>70 \%$ was eliminated in the urine.

The optimal genetics for a production system are those that generate the greatest sustainable economic return (Shalloo et al., 2004). Pryce and Veerkamp (2001) observed a negative correlation between fertility and milk yield. This decline is clearly observed with the HP compared with the NZ genetic strain. The N use efficiency per cow in S2 for the HP genetic strain (22\%) was less than that for the NZ genetic strain (24\%; Table 4); however, the HP genetic strain produced $22 \%$ more surplus $\mathrm{N}$ because of the increased $\mathrm{N}$ required to rear extra replacement animals. The NZ strain produced an average of $523 \mathrm{~kg}$ of MS/cow, which was the equivalent of $4 \mathrm{~kg}$ of MS per $\mathrm{kg}$ of surplus N. The HP genetic strain produced $18 \%$ less MS per $\mathrm{kg}$ of surplus N.

Purchased feed and fertilizer are the most significant sources of $\mathrm{N}$ inputs to a dairy production system, accounting for more than $94 \%$ of all $\mathrm{N}$ inputs to intensive systems (Treacy et al., 2008). Milk and livestock sold are essentially the most significant forms of $\mathrm{N}$ exported (Treacy et al., 2008) and equate to the majority of the economic returns (Shalloo et al., 2004). Combining the economic performance reported by McCarthy et al. (2007) and the $\mathrm{N}$ efficiency reported in this paper, the NZ strain was the most efficient at converting $\mathrm{N}$
Table 6. Herd performance data generated from the Moorepark Dairy Systems Model on the Ryan et al. (2006) dairy production system and environmental data, and reported mean $\mathrm{NO}_{3}$ concentration

\begin{tabular}{lc}
\hline Item & $\begin{array}{c}\text { Herd } \\
\text { performance }\end{array}$ \\
\hline Average number of cows & 101.1 \\
Average yield per cow (kg/cow) & $6,911.2$ \\
Average fat percentage & 4.24 \\
Average protein percentage & 3.64 \\
Average milk solid yield (kg/cow) & 523.64 \\
Average stocking rate (livestock units/ha) & 2.52 \\
Grazing days per year (n) & 279.7 \\
Grazed grass intake (kg of DM/cow) & $3,791.9$ \\
Average silage intake (kg of DM/cow) & $1,050.0$ \\
Concentrate intake (kg of DM/cow) & 664.0 \\
Culling percentage & 24.77 \\
Average $\mathrm{BW}(\mathrm{kg})$ & 535 \\
Mean $\mathrm{NO}_{3}$ concentration $\left(\mathrm{mg}\right.$ of $\left.\mathrm{NO}_{3} / \mathrm{L}\right)$ & 8.05 \\
\hline
\end{tabular}

into saleable product compared with the HP and HD strains.

\section{Nitrogen Losses}

In any intensive agricultural system, the major $\mathrm{N}$ dynamic processes involved in $\mathrm{N}$ loss are volatilization, denitrification, and leaching. The model simulated these processes with close agreement to other simulations and field investigations (Ledgard et al., 1999; Ryan et al., 2001, 2006; Rotz et al., 2006; Watson et al., 2007; Treacy et al., 2008) (Table 5). The pathways by which $\mathrm{N}$ is emitted to the environment are highly variable with a change in production system. Velthof and Oenema (1997) calculated $\mathrm{N}_{2} \mathrm{O}$ emissions from fertilized grasslands in the Netherlands to range from 10 to 20 $\mathrm{kg}$ of N/ha per year and Hyde et al. (2005) measured $\mathrm{N}_{2} \mathrm{O}$ emissions ranging from 2 to $>24 \mathrm{~kg}$ of $\mathrm{N} / \mathrm{ha}$ in Ireland. Dobbie et al. (1999) noted that $\mathrm{N}_{2} \mathrm{O}$ emissions are highly variable depending on temperature and soil moisture. The methods used in this model to quantify losses associated with denitrification do not distinguish between the different forms of $\mathrm{N}$; however, they do assess the quantity of $\mathrm{N}$ diverted away from product, and all losses simulated were similar to previously published losses (Ledgard et al., 1999; Ryan et al., 2001, 2006).

Ledgard et al. (1999) estimated $\mathrm{NH}_{3}$ emissions of between 15 and $78 \mathrm{~kg}$ of $\mathrm{N} / \mathrm{ha}$ for a range of dairy systems with $\mathrm{N}$ input levels ranging from 0 to $400 \mathrm{~kg}$ of $\mathrm{N} /$ ha. As $\mathrm{N}$ fertilizer input increases, so too does $\mathrm{N}$ concentration in herbage consumed (Thompson and Poppi, 1990). Excess $\mathrm{N}$ in the diet is excreted in the dung and urine. The localized deposition of $\mathrm{N}$ in dung and urine by dairy cows results in "hotspots" in the soil. These hotspots in the soil lead to increased risk of $\mathrm{N}$ loss through volatilization of ammonia, denitrification, or leaching of nitrate (Jarvis et al., 1989). 
Comparisons made by del Prado et al. (2006) between estimated biological $\mathrm{N}$ outputs ( $\mathrm{kg}$ of $\mathrm{N} / \mathrm{ha}$ ) from the NCYCLE model (Scholefield et al., 1991) and the NCYCLE_IRL model (del Prado et al., 2006) showed that $\mathrm{N}$ output in the form of $\mathrm{N}$ in milk, urine and dung increased almost linearly as $\mathrm{N}$ intake increased, However, $\mathrm{N}$ output values reported in the literature deviate by up to $80 \%$. Huston et al. (1998) noted that direct measurements of $\mathrm{N}$ losses to air and water are difficult and the coefficient of variation associated with estimates of leaching, runoffs, and volatilization losses are typically in the range of 50 to $200 \%$.

Differences between measured $\mathrm{N}$ loss and predicted $\mathrm{N}$ loss are likely due to inaccurate estimation of background N (O'Connell et al., 2003). The background N from soil mineralization predicted by this model ( 81.7 $\mathrm{kg}$ of $\mathrm{N} / \mathrm{ha}$ ) was similar to that in other studies. Watson and Atkinson (1999) calculated soil N mineralization ranging from 88 to $96 \mathrm{~kg}$ of $\mathrm{N} / \mathrm{ha}$ on a similar soil type in Scotland.

\section{Surplus $\mathbf{N}$}

Surplus N can be considered an indicator of the potential N loss (Scholefield et al., 1991) from dairy production systems. In the systems modeled in this paper, MS production per hectare increased as the $\mathrm{N}$ surplus increased, similar to results of Humphreys et al. (2008). The ratio of MS produced to surplus $\mathrm{N}$ declined with increasing $\mathrm{N}$ surplus. Nitrogen surpluses are assumed to be a good indicator of total $\mathrm{N}$ loss at system level (Scholefield et al., 1991), provided that the whole system can be accounted for. Brockstaller and Girardin (2003) reported that many indicators are not designed to be used to predict an actual effect but to supply information about the potential effect of a production system.

At the system level, $\mathrm{N}$ surplus estimates have proved to be a good predictor of $\mathrm{NO}_{3}{ }^{-}$leaching loss on sandy soils (Fraters et al., 1998; Vellinga et al., 2001), with up to $25 \%$ of $\mathrm{N}$ surplus being leached into groundwater (Fraters et al., 2005). However, the model reported here estimates that approximately $15 \%$ of surplus $\mathrm{N}$ is being leached. The differences may be due to greater $\mathrm{N}$ use efficiency in the systems reported compared with those reported by other authors (Oenema and Heinen, 1999; Fraters et al., 2005; Treacy et al., 2008).

Nitrogen loss studies on grazed swards have shown that calculated $\mathrm{N}$ surpluses generally exceed the measured $\mathrm{N}$ losses (Oenema and Heinen, 1999). The amount of $\mathrm{N}$ not accounted for in this study increases as $\mathrm{N}$ input increases, highlighting the fact that $\mathrm{N}$ movement within agricultural production systems is highly variable and "leaky" (Jarvis et al., 1995). It is possible that the model underestimates $\mathrm{N}$ accumulation in the soil or N losses (Rotz et al., 2006; Watson et al., 2007), or both. Accumulation of organic $\mathrm{N}$ in the soil is highly variable because of variations in the history of the sward, soil, and climate conditions, as well as sward management (Whitehead, 1995; O'Connell et al., 2003; Rotz et al., 2006). Watson et al. (2007) reported that swards receiving $100 \mathrm{~kg}$ of N/ha per year had greater N accumulation than the input - output balance, without considering gaseous emissions, although over the long term, $\mathrm{N}$ within the soil may be leached if not utilized by a growing crop (Ryan et al., 2001).

Using $\mathrm{N}$ surplus as an indicator for estimating $\mathrm{N}$ loss to the environment (volatilized, denitrified, and leached) can sometimes result in an overestimation of losses, because much of the $\mathrm{N}$ surplus within a production system is usually locked up within the soil, crops, and animals. This surplus $\mathrm{N}$ is often in many forms, such as $\mathrm{NH}_{4}$, soluble organic $\mathrm{N}$, and $\mathrm{NO}_{3}{ }^{-}-\mathrm{N}$. The determination of $\mathrm{NO}_{3}$ losses using the difference between the surplus $\mathrm{N}$ from the farm-gate $\mathrm{N}$ balance and the gaseous emissions has disadvantages of accumulating the uncertainties in the $\mathrm{NO}_{3}$ losses (Kristensen et al., 1995) and therefore requires further field-scale investigation.

\section{Model Validation}

In this model, the estimated potential $\mathrm{N}$ leached into groundwater was predicted using the mean effective rainfall (precipitation - evapotranspiration) reported by Ryan et al. (2006) and the adjustment factors for soil type reported by Scholefield et al. (1991) and Schroder et al. (2009). The method used in this study was validated by comparing the groundwater $\mathrm{NO}_{3}$ concentrations estimated by the model with those observed by Ryan et al. (2006). Ryan et al., (2006) studied N leaching for a 3 -yr period at the site where Horan et al. (2004) and McCarthy et al. (2007) measured the biological and physical performance of the dairy production systems examined in this paper. The mean predicted concentration of $\mathrm{NO}_{3}-\mathrm{N}$ for the 9 treatments modeled was $8.1 \mathrm{mg}$ of $\mathrm{NO}_{3}^{-} / \mathrm{L}$; Ryan et al. (2006) reported a mean concentration of $8.2 \mathrm{mg}$ of $\mathrm{NO}_{3}-\mathrm{N} / \mathrm{L}$ at the same site. Richards et al. (1998) observed much higher N leaching results on a similar soil type with double the $\mathrm{N}$ input (up to $677 \mathrm{~kg}$ of $\mathrm{N} / \mathrm{ha}$ ), with $\mathrm{NO}_{3}{ }^{-}-\mathrm{N}$ concentrations measured at $150 \mathrm{~cm}$ deep, ranging from 10 to $54 \mathrm{mg}$ of N/L over a 2-yr period and a farm-gate N surplus ranging from 271 to $340 \mathrm{~kg}$ of $\mathrm{N} / \mathrm{ha}$. Ryan et al. (2001) measured $\mathrm{NO}_{3}-\mathrm{N}$ leaching concentrations ranging from 15.2 to $26.9 \mathrm{mg} / \mathrm{L}$ on fallow ground receiving no fertilizer, which equates to $244 \mathrm{~kg}$ of $\mathrm{N} /$ ha leached. Travel time of $\mathrm{N}$ to groundwater (Lord and Anthony, 
2000; Dunn et al., 2004; Richards et al., 2005) is highly variable between soil types. Boumans et al. (2001) and Sonneveld et al. (2008) reported that varying levels of precipitation combined with contrasting $\mathrm{N}$ surpluses results in varying $\mathrm{N}$ concentrations in groundwater. Fraters et al. (2005) reported a reduction in $\mathrm{NO}_{3}{ }^{-} \mathrm{N}$ concentration in groundwater, and that all known environmental factors could only account for $50 \%$ of the reduction in groundwater $\mathrm{NO}_{3}{ }^{-}-\mathrm{N}$ concentration.

\section{Modeling N Use Efficiency}

In recent years, $\mathrm{N}$ use management has become particularly important in grass-based systems, as the efficiency at which $\mathrm{N}$ is used strongly influences the production, agronomic, and environmental performance (Jarvis et al., 1995) of these systems. Recent changes in European policies dictate that $\mathrm{N}$ must be used more efficiently. However, $\mathrm{N}$ use management at the farm level is complex, and achieving a suitable balance between sustainable levels of production and minimizing $\mathrm{N}$ loss is challenging. Limited information exists on the management and monitoring of $\mathrm{N}$ flows in grassland at a whole-farm level with many unknowns in the pathways of $\mathrm{N}$; for example, information on denitrification and soil N mineralization is limited (Whitehead, 1995; O'Connell et al., 2003; Watson et al., 2007).

The means by which the $\mathrm{N}$ surplus at a system level is calculated is crucial to ensure that all systems are represented accurately. The scenarios investigated in this paper show that the assessment of production systems using different system boundaries return different $\mathrm{N}$ surpluses and therefore different $\mathrm{N}$ use efficiency.

The production and economic consequences of alternative management practices and the genetic make-up of animals in production systems under Irish conditions has previously been reported by Dillon et al. (1995), Horan et al. (2004), Shalloo et al. (2004), and McCarthy et al. (2007). However, these authors did not investigate the effect of different production systems on $\mathrm{N}$ balance and efficiency, or potential environmental consequences.

Many researchers use farm-gate $\mathrm{N}$ inputs and $\mathrm{N}$ outputs to assess the potential $\mathrm{N}$ losses; this method of assessing $\mathrm{N}$ use efficiency may not fully account for all the $\mathrm{N}$ losses from that production system. In many $\mathrm{N}$ balance studies, the rearing of replacement animals required to maintain the production system (as described in S2) are not accounted for. Thus, the potential exists for misleading inference. The simple farm-gate balance calculated in $\mathrm{S} 1$ on a per cow basis highlights that the high-production genetic strain combined with the high stocking rate feeding system (HP-HS) utilized $\mathrm{N}$ most efficiently (0.34) when $\mathrm{N}$ required to rear replacement animals was not accounted for; however, when the full production system was accounted for, in $\mathrm{S} 2$, the $\mathrm{N}$ surplus for the production system with NZ genetics, regardless of production system, produced an average of $21 \%$ less surplus $\mathrm{N}$ than the HP-HC production system and 15\% more MS than the other genetic strains. Replacement animals are an integral part of the system and should be included, as they are in financial comparisons (Shalloo et al., 2004).

\section{CONCLUSIONS}

Models are effective tools to predict the effects of contrasting production systems and land-use options. The simulated results predicted $\mathrm{N}$ leaching with a close association to observed results at this site. These results create awareness and concerns about the indicators to assess environmental sustainability of intensive grassland systems. The results of the current study demonstrated that within pasture-based systems the lowest $\mathrm{N}$ losses and maximum profitability were observed with the Holstein-Friesian cows, combining high genetic potential for both production and fertility traits (HD and NZ strains), rather than those selected solely for increased milk production potential (HP strain). The whole-system approach of full accounting facilitates the comprehensive understanding of a system and an insight to the interactions and relationships between $\mathrm{N}$ flows and potential $\mathrm{N}$ losses, within and outside the farm boundaries, creating an indicator for management practices to assess the environmental consequences.

\section{ACKNOWLEDGMENTS}

This project was funded by the Research Stimulus Fund 2005 administered by the Department of Agriculture, Fisheries and Food (RSF 05-201).

\section{REFERENCES}

ARC. 1994. The nutrient requirements of ruminant livestock. Technical review by an Agricultural Research Council Working Party. CAB International, Wallingford, UK.

Boumans, L. J. M., B. Fraters, and G. Van Drecht. 2001. Nitrate in the upper groundwater of 'De Marke' and other farms. NJAS-Wagen. J. Life Sci. 49:136-177.

Brockstaller, C., and P. Girardin. 2003. How to validate environmental indicators. Agric. Syst. 73:639-653.

Castillo, A. R., E. Kebreab, D. E. Beever, and J. France. 2000. A review of efficiency of nitrogen utilisation in dairy cows and its relationship with the environmental pollution. J. Anim. Feed Sci. $9: 1-32$.

Corrall, A. J., and J. S. Fenlon. 1978. A comparative method for describing the seasonal distribution of production from grasses. J. Agric. Sci. (Camb.) 91:61-67.

Delaby, L., M. L. Decau, J. L. Peyraud, and P. Accarie. 1997. AzoPât: Une description quantifiée des flux annuels d'azote en prairie pâturée par les vaches laitières. 1. Les flux associés à l'animal. Fourrages 151: 297:311. 
del Prado, A., L. Brown, R. Schulte, M. Ryan, and D. Scholefield. 2006. Principles of development of a mass balance N cycle model for temperate grasslands: An Irish case study. Nutr. Cycl. Agroecosys. 74:115-131.

Dillon, P., S. Crosse, G. Stakelum, and F. Flynn. 1995. The effect of calving date and stocking rate on the performance of springcalving dairy cows. Grass Forage Sci. 50:286-299.

Dillon, P., J. R. Roche, and L. Shalloo. B, Horan. 2005. Optimising financial return from grazing in temperate pastures. Pages 131-147 in Utilisation of grazed grass in temperate animal systems. Proceedings of a satellite workshop of the XXth International Grassland Congress, July 2005, Cork, Ireland. J. J. Murphy, ed. Wageningen Academic Publishers, Wageningen, the Netherlands.

Dobbie, K. E., I. P. McTaggart, and K. A. Smith. 1999. Nitrous oxide emissions from intensive agricultural systems: Variations between crops and seasons, key driving variables, and mean emissions factors. J. Geophys. Res. 104:26891-26899.

Dunn, S. M., A. J. A. Vinten, A. Lilly, J. Degroote, M. A. Sutton, and M. Gechan. 2004. Nitrogen Risk Assessment Model for Scotland. I. Nitrogen Leaching. Hydrol. Earth Syst. 8:191-204.

EPA. 2006. Water Quality in Ireland 2004-2006. Key Indicators of the Aquatic Environment Compiled by John Luceya. Aquatic Environment Office of Environmental Assessment Environmental Protection Johnstown Castle, Wexford, Ireland. Accessed January 31, 2010. http://www.epa.ie/downloads/pubs/water/indicators/ epa_water_quality_indicators1.pdf.

European Council. 1991. Directive 91/676/EEC concerning the protection of waters against pollution caused by nitrates from agricultural sources. Off. J. L 375(31/12/1991):1-8.

Fraters, B., L. J. M. Boumans, G. Van Drecht, T. De Haan, and W. D. De Hoop. 1998. Nitrogen monitoring in groundwater in the sandy regions of the Netherlands. Environ. Pollut. 102:479-485.

Fraters, D., L. J. M. Boumans, T. C. van Leeuween, and W. D. de Hoop. 2005. Results of 10 years of monitoring nitrogen in the sandy regions in the Netherlands. Water Sci. Technol. 51:239-247.

Haynes, R. J., and P. H. Williams. 1993. Nutrient cycling and soil fertility in the grazed pasture ecosystem. Adv. Agron. 49:171-173.

Horan, B., J. F. Mee, M. Rath, P. O'Connor, and P. Dillon. 2004. The effect of strain of Holstein-Friesian cow and feed system on reproductive performance in seasonal-calving milk production systems. Anim. Sci. 79:453-467.

Humphreys, J., I. A. Casey, and O. T. Carton. 2003. Meeting environmental objectives and potential constraint on dairy production in Ireland. Pages 145-164 in Nutrient Management at Farm Scale: How to Attain Policy Objectives in Regions with Intensive Dairy Farming. J. Bos, F. Aarts, F. Vertes, and A. Pflimlin, ed. Wageningen Press, the Netherlands.

Humphreys, J., K. O'Connell, and I. A. Casey. 2008. Nitrogen flows and balances in four grassland-based systems of dairy production on a clay-loam soil in a moist temperate climate. Grass Forage Sci. $63: 467-480$

Hutchings, J. N., and I. S. Kristeensen. 1995. Modelling mineral nitrogen accumulation in grazed pasture: Will more nitrogen leach from fertilized grass than unfertilized grass/clover? Grass Forage Sci. 50:300-313

Huston, J. L., R. E. Pitt, R. K. Koelsch, J. B. Houser, and R. J. Wagenet. 1998. Improving dairy farm sustainability. II: Environmental losses and nutrient flows. J. Prod. Agric. 11:233-239.

Hyde B., M. Ryan, M. Hawkins, J. Connolly, and O. T. Carton, 2005. Nitrous oxide emissions. End of project report RMIS 4974. Johnstown Castle Research Centre, Wexford, Ireland.

Hyde, B. P., O. T. Carton, P. O'Toole, and T. H. Misselbrook. 2003. A new inventory of ammonia emissions from Irish agriculture. Atmos. Environ. 37:55-62.

Jarrige, R. E. 1989. Ruminant Nutrition-Recommended Allowances and Feed Tables. INRA, Paris, France.

Jarvis, S. C., D. J. Hatch, and D. H. Roberts. 1989. The effects of grassland management on nitrogen losses from grazed swards through ammonia volatilization: The relationship to excretal returns form cattle. J. Agric. Sci. (Camb.) 112:205-216.
Jarvis, S. C., D. Scholefield, and B. F. Pain. 1995. Nitrogen cycling in grazing systems. Pages 381-419 in Nitrogen Fertilisation in the Environment. P. E. Bacon, ed. Marcel Dekker, New York, NY.

Kristensen, E. S., H. Høgh-Jensen, and I. S. Kristensen. 1995. A simple model for estimation of atmospherically-derived nitrogen in grassclover systems. Biol. Agric. Hortic. 12:263-276.

Laws, J. A., B. F. Pain, S. C. Jarvis, and D. Scholefield. 2000. Comparison of grassland management systems for beef cattle using self-contained farmlets: Effects of contrasting nitrogen inputs and management strategies on nitrogen budgets, and herbage and animal production. Agric. Ecosyst. Environ. 80:243-254.

Ledgard, S. F., J. W. Penno, and M. S. Sprosen. 1999. Nitrogen inputs and losses from clover pastures grazed by dairy cows affected by nitrogen fertilizer application. J. Agric. Sci. (Camb.) 132:215-225.

Lord, E. L., and S. G. Anthony. 2000. MAGPIE: A modelling framework for evaluating nitrate losses at national and catchments scales. Soil Use Manage. 16:167-174.

McCarthy, S., B. Horan, P. Dillon, P. O'Connor, M. Rath, and L. Shalloo. 2007. An economic comparison of three divergent strains of Holstein-Friesian dairy cows in various pasture-based milk production systems. J. Dairy Sci. 90:1493-1505.

McDonald, P., R. A. Edwards, J. F. D. Greenhalgh, and C. A. Morgan. 1995. Animal Nutrition. 5th ed. Addison Wesley Longman Ltd, Edinburgh Gate, Harlow, Essex, UK.

Misselbrook, T.H., D.R. Chadwick, B.J. Chambers, K.A. Smith, J. Webb, T. Demmers, and R.W. Sneath, 2006. Inventory of ammonia emissions from UK agriculture 2004, DEFRA contract AM0127, Inventory submission report March 2006. Defra, London, UK.

Mounsey, J., J. Sheehy, O. T. Carton, and P. O'Toole. 1998. Nutrient management planning on Irish dairy farms. End of project report, ARMIS 4347. Teagasc, Dublin, Ireland.

O'Connell, K., J. Humphreys, and C. J. Watson. 2003. Quantification of nitrogen sources for grassland. Proc. Fert. Assoc. Ireland 40:15-29.

Oenema, O., and M. Heinen. 1999. Uncertainties in nutrient budgets due to biases and errors. Pages 75-97 in Nutrient Disequilibria in Agroecosystems: Concepts and Case Studies. E. M. A. Smaling, O. Oenema, and L. O. Fresco, ed. CABI Publ., New York, NY.

Pain, B. F., V. R. Philips, C. R. Clarkson, and J. V. Klarenbeek. 1989. Loss of nitrogen through ammonia volatilization during and following the application of pig or cattle slurry to grassland. J. Sci. Food Agric. 47:1-12.

Pain, B. F., R. B. Thompson, Y. J. Rees, and J. H. Skinner. 1990 Reducing gaseous losses on nitrogen from cattle slurry applied to grassland by the use of additives. J. Sci. Food Agric. 50:141153

Peyraud, J. L., and L. Astigarraga. 1998. Review of the effect of nitrogen fertilisation on the chemical composition, intake, digestion and nutritive value of fresh herbage: Consequences on animal nutrition and $\mathrm{N}$ balance. Anim. Feed Sci. Technol. 72:235-259.

Peyraud, J. L., L. Astigarraga, and P. Faverdin. 1997. Digestion of fresh perennial ryegrass fertilised at two levels of nitrogen by lactating dairy cows. Anim. Feed Sci. Technol. 64:155-171.

Pryce, J. E., and R. F. Veerkamp. 2001. The incorporation of fertility indices in genetic improvement programmes. Pages 237-249 in Fertility in the High Producing Dairy Cow. Occasional Publication 26. Br. Soc. Anim. Sci., Edinburgh, UK.

Richards, K. 1999. Sources of nitrate leached to groundwater in grasslands of Fermoy, Co. Cork. PhD thesis. Trinity College Dublin, Ireland.

Richards, K., C. E. Coxon, and M. Ryan. 2005. Unsaturated zone travel time to groundwater on a vulnerable site. Ir. Geogr. 38:57-71.

Richards, K., M. Ryan, and C.E. Coxon. 1998. Leaching of N compounds from wastes used for dairying that are N-based and irrigated with dirty water/slurry. End of project report ARMIS 3635. Teagasc, Johnstown Castle Research Centre, Wexford, Ireland.

Rotz, C. A., J. Oenema, and H. Van Keulen. 2006. Whole farm management to reduce nutrient losses from dairy farms: A simulation study. Appl. Eng. Agric. 22:773-784. 
Rotz, C. A., F. Taube, M. P. Russell, J. Oenema, M. P. Sanderson, and M. Wachendorf. 2005. Whole-farm perspectives of nutrient flows in agriculture. Crop Sci. 45:2139-2159.

Ryan, M., C. Brophy, J. Connolly, K. McNamara, and O. T. Carton. 2006. Monitoring of nitrogen leaching on a dairy farm during four drainage seasons. Ir. J. Agric. Food Res. 45:115-134.

Ryan, M., M. Sherwood, and A. Fanning. 2001. Leaching of nitrate-N $\left(\mathrm{NO}_{3}-\mathrm{N}\right)$ from cropped and fallow soil-A lysimeter study with ambient and imposed rainfall regimes. Ir. Geogr. 34:34-49.

Scholefield, D., D. R. Lockyer, D. C. Whitehead, and K. C. Tyson. 1991. A model to predict transformations and losses of nitrogen in UK pastures grazed by beef cattle. Plant Soil 132:165-177.

Schroder, J. J., H. F. M. Aarts, J. C. Van Middelkoop, G. L. Velthof, J. W. Reijs, and B. Fraters. 2009. Nitrates Directive requires limited inputs of manure and mineral fertilizer in dairying farming systems. Report 222. Plant Research International B.V., Wageningen, the Netherlands.

Shalloo, L., P. Dillon, M. Rath, and M. Wallace. 2004. Description and validation of the Moorepark Dairy System Model. J. Dairy Sci. 87:1945-1959.

Sonneveld, M. P. W., J. J. Schroder, J. A. de Vos, G. J. Monteny, J. M. Mosquera, E. A. Lantinga, F. P. M. Verhoeven, and J. Bouma. 2008. A whole-farm strategy to reduce environmental impacts of nitrogen. J. Environ. Qual. 37:186-195.

Teagasc. 2007. National Farm Survey. Teagasc, Athenry, Ireland.

Teagasc. 2008. Management data for farm planning. Teagasc, Dublin Ireland

Thompson, K. F., and D. P. Poppi. 1990. Livestock production from pasture. Pages 263-283 in Pastures: Their Ecology and Management. R. H. M. Langer, ed. Oxford University Press, Melbourne, Australia.

Treacy, M., J. Humphreys, K. Mc Namara, R. Brown, and C. J. Watson. 2008. Farm-Gate nitrogen balances on intensive dairy farms in the south west of Ireland. Ir. J. Agric. Food Res. 47:105-117.
Van der Meer, H. G. 1983. Effective use of nitrogen on grassland farms. Pages 61-68 in Proc. 9th General Mtg. Eur. Grassl. Fed., Reading, UK. A. J. Corral, ed.

Van Vuuren, A. M., and J. A. C. Meijs. 1987 Effects of herbage composition and supplement feeding in the excretion of nitrogen in dung and urine by grazing dairy cows. Pages 15-48 in Animal Manure on Grassland and Fodder Crops. Fertilizer or Waste? H. G. van der Meer, R. J. Unwin J. A. Dijk, and G. C. Ennik, ed. Martinus Nijhoff, Dordrecht, the Netherlands.

Vellinga, T. H. V., A. H. J. Van Der Putten, and M. Mooij. 2001 Grassland management and nitrate leaching, a model approach. NJAS-Wagen. J. Life Sci. 49:229-253.

Velthof, G. L., and O. Oenema. 1997. Nitrous oxide emission from dairy farming systems in the Netherlands. NJAS-Wagen. J. Life Sci. $45: 347-360$.

Verite, R., and L. Delaby., 2000. Relation between nutrition, performances and nitrogen excretion in dairy cows. Ann. Zootec. 49:217-230.

Watson, C. A., and D. Atkinson. 1999. Using nitrogen budgets to indicate nitrogen use efficiency and losses from whole farm systems: A comparison of three metrological approaches. Nutr. Cycl. Agroecosys. 53:259-267.

Watson, C. A., D. Atkinson, P. Gosling, L. R. Jackson, and F. W. Rayns. 2002. Managing soil fertility in organic farming systems. Soil Use Manage. 18:239-247.

Watson, C. J., C. Jordan, D. Kilpatrick, B. McCarney, and R. Stewart. 2007. Impact of grazed grassland management on total $\mathrm{N}$ accumulation in soil receiving different levels of $\mathrm{N}$ inputs. Soil Use Manage. 23:121-128.

Whitehead, D. C. 1970. The Role of Nitrogen in Grassland Productivity. Commonwealth Agriculture Bureaux, Farnham Royal, UK.

Whitehead, D. C. 1995. Grassland Nitrogen. CAB International, Wallingford, UK. 